\title{
ENTRE O REPRIMIDO E O LIBERTO: UMA LEITURA DO CORPO EM MULHER NO ESPELHO, DE HELENA PARENTE CUNHA
}

\author{
SILVANA NASCIMENTO LIANDA ${ }^{1}$ \\ Universidade do Estado da Bahia, Programa de Pós-graduação em Crítica Cultural \\ Rodovia Alagoinhas, Salvador - BR 110, KM 03 - Alagoinhas (BA) - Brasil
}

\section{sil lianda@hotmail.com}

\begin{abstract}
Resumo. $O$ estudo discute os processos repressivos expressos no romance Mulher no Espelho, de Helena Parente Cunha, e o modo como estes direcionam as ações da personagem central. Foram realizadas leituras a respeito do contexto social de escrita e publicação da obra, bem como acerca de repressão, corpo e psicanálise. Assim, a partir de uma fundamentação baseada, principalmente, em Marilena Chaui (1991) e Sigmund Freud (1975) verificou-se a tentativa da personagem de romper com a ordem repressiva na qual foi criada. Porém, vencida pelas pressões que constituíram o corpo aprisionado, a personagem permanece imersa no mesmo conflito psíquico entre o impulso do prazer almejado e a pressão da realidade repressora ao qual estivera condicionada no início da trama.
\end{abstract}

Palavras-chave: Mulher no Espelho; repressão; corpo; psicanálise.

\begin{abstract}
The study discusses the repressive processes expressed in the novel Woman in the Mirror by Helena Parente Cunha and the way in which they direct the actions of the central character. Readings were made regarding the social context of writing and publication of the work, as well as about repression, body and psychoanalysis. Thus, based on a foundation based mainly on Marilena Chaui (1991) and Sigmund Freud (1975), the character's attempt to break with the repressive order in which she was created was verified. However, overcome by the pressures that constituted the imprisoned body, the character remains immersed in the same psychic conflict between the impulse of the desired pleasure and the pressure of the repressive reality that had been conditioned at the beginning of the plot.
\end{abstract}

Keywords: Woman in the Mirror; repression; body; psychoanalysis.

\section{INTRODUÇÃO}

O presente trabalho tendo como tema os processos de repressão e aprisionamento do corpo expressos na obra Mulher no Espelho visa identificar os processos de repressão vivenciados pela personagem central de tal romance, considerando seu corpo como um possível espaço de aprisionamento. O estudo foi realizado com base em Marilena Chauí

\footnotetext{
${ }^{1}$ Mestre em Crítica Cultural pela Universidade do Estado da Bahia, UNEB.
} 
(1991), Sigmund Freud (1975), Carl Jung (1991), Ronald David Laing (1989) e Sheila Ferreira Leite (2004).

Helena Parente Cunha ${ }^{2}$ apresenta no romance em questão uma trama de caráter psicológico na qual uma mulher que não teve seus desejos exteriorizados passa a recontar sua história, a princípio aparentemente satisfatória. A personagem principal se encontra em fase de imersão em suas lembranças, condição essa impulsionada pela "mulher que me escreve", representando o diálogo com a personagem frente ao espelho. Por meio de um fluxo de memórias que insistem em ser relembradas e refletidas, a narradorapersonagem é induzida a um processo de afirmação e reafirmação de ações passadas, bem como de questionamento de tantas outras. A história contada pela personagem-narradora é intercalada por falas da mulher que a escreve, apresentando ao leitor outro olhar sobre os acontecimentos narrados.

Assim, considerando o corpo da personagem como um possível espaço de aprisionamento e as leituras realizadas acerca de questões abordadas na trama e relacionadas ao estudo aqui proposto, avaliou-se os processos repressivos relatados na obra e como estes processos direcionam as ações da personagem, verificando os mecanismos que conduziram/ construíram seu corpo como um possível espaço de aprisionamento.

\section{A ESCRITA DE MULHER NO ESPELHO: CONTEXTO DE CRIAÇÃO E TEMÁTICAS QUE A CONSTITUEM}

A escritora comenta ter enfrentado calúnias após o lançamento de Mulher no Espelho, pois passaram a confundir o eu biográfico do romance com o eu da narradora supondo ser Helena Parente Cunha a personagem inominada da narrativa que atacava a moral de fachada. Ela afirma que sua obra representa a vivência desta na ordem patriarcal carregada de todo ônus com que a distinção hierarquizante dos gêneros sufocou a mulher e acrescenta que, assim como a protagonista de Mulher no Espelho, ela nasceu e viveu em Salvador, em um ambiente que conservava fortemente tradições familiares e discriminações sociais. Tal vivência foi grande motivador para a escrita da obra e sua carga de criticidade e repúdio aos modos de vida nela representados, porém, conforme relatos da autora, pode também ter sido a grande motivadora de um período depressivo enfrentado pela escritora logo após o seu lançamento.

Relata, portanto, o rígido modelo patriarcal em que fora criada, de modo que somente após o vendável dos anos 60, que derrubou códigos culturais, sentiu-se encorajada o suficiente para atacá-lo em sua escrita. "Por certo, só após aquela abertura, senti-me encorajada a desafiar a pesada censura do mundo patriarcal que havia bloqueado qualquer impulso meu para colocar no papel a revolta e indignação que eu sentia diante daquela estrutura autoritária" (CUNHA, 2004, p. 14). A escritora afirma ser tal romance o carro-chefe de sua produção literária, embora esteja longe de ser seu livro preferido. E complementa que se trata de uma narrativa na qual os abusos da dominação masculina

\footnotetext{
${ }^{2}$ Helena Parente Cunha cursou Letras Neolatinas na antiga Faculdade de Filosofia, da UFBA. Possui os títulos de Pós-Doutorado e Livre Docência pela UFRJ, Doutorado em Letras pela UFSC, Mestrado em Letras pela UFRJ. É ensaísta, poeta, contista, romancista, professora e tradutora. Pertence a agremiações literárias, entre as quais a Academia de Letras da Bahia, o PEN Clube, a União Brasileira de Escritores. Discute, principalmente, temáticas como: literatura de autoria feminina, mulher e literatura brasileira, gênero, violência simbólica, modernidade e pós-modernidade.
} 
são representados num tom ácido de revolta e sarcasmo contra as injustiças impostas a várias camadas de excluídos, de modo que publicado no início dos anos 80 , devido a certas passagens mais ousadas, o livro chocou e foi considerado indecoroso por muitos. A esse respeito, cita a recepção pelos leitores.

Na época, 1983, o romance melindrou muita gente, devido à violência do protesto contra a situação da protagonista que, na primeira fase se mostra inteiramente incapaz de vontade própria, sem coragem para identificar seus desejos, enfim, sem possibilidade para se reconhecer como sujeito. Mas o que chocou os desavisados leitores foi sobretudo a mudança da protagonista, quando decide reverter a situação e passa a viver todos os itens da lista de proibições a que deveriam obedecer as moças e senhoras de boa família, além de exibir, às vezes um tanto cinicamente, suas novas convicções libertárias. (CUNHA, 2004, p. 14)

A recepção das pessoas diante das semelhanças encontradas, considerando o comportamento da personagem na primeira fase do romance como o fato de haver morado em bairros onde a escritora da obra morou, além do perfil de Helena Parente Cunha definido como o de uma pessoa calma, gerou impacto nos leitores diante da mudança sofrida pela personagem no decorrer da trama. A protagonista que inicialmente mostrouse calma na sua submissão e subserviência ao pai e posteriormente ao marido, além de tomada por complexos de inferioridade e rejeição a partir do nascimento do seu irmão, tem seu comportamento modificado ao extremo oposto em relação ao seguido até tal momento. Essa transformação da personagem somada às semelhanças que encontravam entre a protagonista e a autora até então provocaram nos leitores uma mudança de comportamento para com Helena Parente Cunha. A escritora relata que alguns passaram a considerá-la disponível para vivenciar as práticas sexuais da personagem narrada na trama, enquanto outros cortaram relações considerando-a inadequada para seu meio de convívio.

No tocante aos aspectos temáticos de Mulher no Espelho, em tal romance são ilustrados aprisionamentos do corpo no que se refere ao psicológico, ao físico, pelo outro e por si. A personagem se vê aprisionada por seus traumas, constituídos ainda na infância e intensificados com o passar dos anos, traumas estes discutidos pela "mulher que me escreve" (conforme cita a personagem). Ela se vê aprisionada pelos limites de seu corpo físico, relatando o cansaço a que chegou já sem energia para reações e sentimentos; se vê aprisionada por sua família, inicialmente pelo irmão e pelos pais e durante sua vida adulta pelo marido e os filhos, além das influências de conhecidos da família que criticam seu comportamento. Ao longo da trama vai sendo apresentado também o comportamento de auto aprisionamento, de autocensura, a partir dos relatos da mulher que a escreve, como se a origem dos demais aprisionamentos estivesse centrada no modo como a personagem se vê no mundo.

A linguagem apresenta caráter de diário ou autoanálise em divã, uma vez que a narração é feita pela personagem principal da história (em primeira pessoa), embora haja interrupções feitas pela mulher que a escreve em forma de diálogo com a personagem central. Tais diálogos são feitos em segunda pessoa, marcados em itálico e vão aparecendo cada vez com menos frequência ao longo da narrativa. Há uma interação com o leitor que vai sendo lançado em meio aos discursos contrários de ambas (a personagem e a mulher que a escreve) e testemunhando versões diferenciadas da mesma história. 
Os espelhos mencionados na obra funcionam como uma espécie de divã, representando momentos de autoanálise vivenciados pela personagem. Assim, há entre os espelhos e a personagem a relação de repulsa e de atração, uma vez que este representa o reflexo da autoimagem, o reflexo de seus medos e submissão, bem como o reflexo de sua aparente quebra com os aprisionamentos.

A mulher que a escreve, por sua vez, configura-se na narrativa como sua própria consciência, o reflexo dos espelhos, sua criação e sua criadora, sua face inicialmente rebelde e posteriormente moldada aos preceitos sociais, vivência inversa à sua. Essa "mulher que me escreve", como a chama a personagem central, é diferenciada da autora da obra como se a autora fosse ainda uma terceira entidade na trama. Essa questão é relatada por Sheila Ferreira Leite na citação a seguir.

O que se evidencia, no romance ora tratado, é a presença de três entidades: eu (a personagem-narradora), ela (a mulher que escreve a história) e a autora que simula comandá-las ou que é comandada por elas e que, ao mesmo tempo, é o resultado do jogo eu-com-ela. (LEITE, 2004, p. 155)

A história, portanto, surge a partir do enfrentamento entre a personagem e a mulher que a escreve, de modo que o enredo é marcado por digressões em um tempo predominantemente psicológico. Há ainda a delimitação do espaço físico, sendo a cidade de Salvador, especialmente o bairro do Rio Vermelho, embora predomine o espaço psicológico.

\section{REPRESSÃO SEXUAL: ASPECTOS SOCIAIS E FAMILIARES CONFIGURANDO TRAUMAS DA PERSONAGEM}

Na obra Mulher no Espelho a personagem sofre com uma série de proibições que permeiam tanto sua infância e adolescência, quanto sua vida adulta. O controle exacerbado, inicialmente exercido por seu pai, posteriormente passa a ser desempenhado por seu marido. E ao longo da narrativa vão sendo apresentadas ao leitor as motivações para sua infância e adolescência reprimidas, bem como as contribuições para sua fase adulta omissa.

Um aspecto que permeia toda a formação da personagem consiste na repressão de sua sexualidade, tal nível repressivo é definido por Marilena Chauí (1991) como um conjunto de interdições, normas, regras e valores estabelecidos historicamente e culturalmente pela religião, moral e ciência para controlar o exercício da sexualidade. Ela complementa que as proibições e permissões são interiorizadas pela consciência individual graças a inúmeros procedimentos sociais e expulsas para longe da consciência quando transgredidas, porque neste caso provocam sentimentos de dor, sofrimento e culpa que se deseja esquecer ou ocultar. Assim, a repressão sexual será tanto mais eficaz quanto mais conseguir ocultar, dissimular e disfarçar o caráter sexual daquilo que esta sendo reprimido. Nesse sentido, a personagem da obra Mulher no Espelho revela ao longo da trama seu total desconhecimento por qualquer termo relativo à sexualidade: "Eu era uma menina ingênua e sozinha, sem ninguém que me ajudasse a ter coragem de romper o cerco das proibições de meu pai, sem ninguém que me explicasse o que significavam palavras como virgindade, que nem de longe eu suspeitava o que fosse" (CUNHA, 2001, p. 83). 
No referente à definição do termo, Marilena Chauí defende que repressão, segundo os estudos da psicanálise, é a operação psíquica tendente a fazer desaparecer da consciência um conteúdo desagradável ou inoportuno, conteúdo que pode ser apenas uma ideia. E considerando os estudos psicanalíticos no que diz respeito ao alcance do ego e sua relação com as repressões, Sigmund Freud afirma:

formamos a ideia de que em cada indivíduo existe uma organização coerente de processos mentais e chamamos a isso o seu ego. É a esse ego que a consciência se acha ligada: o ego controla as abordagens à motilidade - isto é, à descarga de excitações para o mundo externo. Ele é a instância mental que supervisiona todos os seus próprios processos constituintes e que vai dormir à noite, embora ainda exerça a censura sobre os sonhos. Desse ego procedem também as repressões, por meio das quais procura-se excluir certas tendências da mente. (FREUD, 1975, p. 26)

Em relação à internalização de situações desagradáveis, Jean Laplanche e JeanBertrand Pontalis (1986), no dicionário de psicanálise, conceituam o trauma como um acontecimento da vida do indivíduo que se define pela sua intensidade, pela incapacidade em que este se acha de lhe responder de forma adequada e pelo transtorno e efeitos patogênicos duradouros que lhe provoca na organização psíquica. Ou seja, o traumatismo caracteriza-se por um afluxo de excitações que é excessivo à tolerância do indivíduo e à capacidade deste de dominar e elaborar psiquicamente estas excitações.

E, em complemento ao exposto, sobre o complexo afetivo Carl Gustav Jung (1991) discute que consiste na imagem de uma determinada situação psíquica de forte carga emocional e incompatível com as disposições ou atitude habitual da consciência. Segundo ele esta imagem é dotada de poderosa coerência interior e tem sua totalidade própria e goza de um grau relativamente elevado de autonomia. Está sujeita ao controle das disposições da consciência até certo limite e, por isto, se comporta na esfera do consciente como um corpo estranho animado de vida própria. Assim, alega que com algum esforço de vontade pode-se reprimir o complexo, mas é impossível negar sua existência e na primeira ocasião favorável ele volta à tona com toda a sua força original.

Na obra Mulher no Espelho a personagem, na rememoração das fases de sua vida, vai repensando todos os acontecimentos que ilustram os vários complexos por ela interiorizados. No choque de visões, interpretações e relatos a personagem começa citando toda a sua vivência como normal e até satisfatória, ao passo que a mulher que a escreve focaliza os aspectos reais dessa existência, aspectos negativos e traumáticos para a personagem e que a condicionaram a viver de modo submisso e omisso. Uma das situações relatada foi a utilização do batom vermelho que a personagem fez contrariando a vontade de seu pai e o resultado dessa desobediência.

O batom, sua tia lhe deu no seu aniversario de 18 anos. Todas as moças de 18 anos usavam batom. Você se olhou muito no espelho, a boca vermelha, você se achou bonita. Foi dizer até logo a seu pai. [...] Então o seu irmão que não ia ao cinema com você, disse papai ela está de batom. Você se lembra? Seu pai mandou abrir as janelas, o que é isto? Sua mãe saiu de perto. Seu pai pegou uma toalha de rosto que estava perto da cama, uma toalha felpuda, e começou a esfregar na sua boca, esfregando, esfregando, muito zangado, dizendo que filha dele não ia andar daquele jeito na rua. Você não arredava o pé e ainda oferecia mais o rosto para ele maltratar, até começar a sangrar, ele dizendo, não é 
assim que você quer? Está aí, vermelho como você quer, todo vermelho $^{3}$. (CUNHA, 2001, p. 59)

Ao mesmo tempo é descrito o sentimento de culpa que se apoderou da personagem por ter desobedecido às ordens expressas por seu pai e o olhar da mulher que a escreve acerca desse comportamento.

Você entrou em desespero como se tivesse praticado um crime. Seu pavor imaginando que seu pai poderia morrer por sua causa, ele doente, devendo manter-se em repouso, e você aproveitando da situação. O mínimo que você podia fazer, já que não tinha coragem de o enfrentar e impor a sua vontade. Você nunca se perdoou por ter enganado seu pai. (CUNHA, 2001, p. 60)

Outro acontecimento relatado foi a escrita do diário pela personagem. A menina solitária e introvertida via a necessidade de algo ou alguém que lhe servisse de apoio, de companhia, de confidente e, com base nisso, conferiu ao seu diário informações ambíguas, porém, com interpretações diferenciadas das que seu pai lhe atribuiu. Acerca desse diário, a personagem afirma:

um dia, a descoberta do meu diário transgressor. Aos dezessete anos, a necessidade de registrar certas impressões. Naquele tempo, dei ao meu travesseiro o nome de Jhonny. Jhonny era o meu amigo fiel, consolador das minhas lágrimas, os meus acessos de choro assomando, eu não sabia por quê. O meu diário se chama Franky. Jhonny e Franky, meu consolo e meu esteio. (CUNHA, 2001, p. 80)

O conteúdo de tal escrita, consequentemente, ao ser descoberto por seu pai motivou uma reação inesperada, como a personagem acrescenta a seguir.

Eu ignorava o significado de virgindade. No meu diário, eu registrava os meus passos no desconhecimento do sexo. Usava palavras cuja ambigüidade eu desconhecia por puro desconhecimento. Vocês são capazes de imaginar o espanto que se apoderou de mim quando, ao voltar da aula, encontrei meu pai possesso, o diário numa das mãos gesticulando, vermelho, o cabelo caído na testa, a testa cruzada de rugas verticais e horizontais. Sua vagabunda. O cinturão de couro tremia na outra mão. Papai, pelo amor de Deus, o que foi que eu fiz? Sua imoral, sua perdida, sua desgraçada. Minha mãe desmaiou. E ainda por cima o que ela faz com a mãe. As marcas do cinto em meu corpo começando a sangrar. (CUNHA, 2001, p. 83)

E do mesmo modo como reagia diante de qualquer contrariedade às regras de seu pai, o sentimento de remorso que se apoderava da personagem, como resposta ao comportamento dominante do mesmo, é perceptível no trecho: “[...] tome, pode rasgar o meu diário, pode queimar o meu travesseiro, adeus Jhonny, adeus Franky" (CUNHA, 2001, p. 84).

\footnotetext{
${ }^{3}$ Parte da obra Mulher no Espelho é grafada em itálico. Tal marcador foi utilizado pela autora para diferenciar os fragmentos em que a história contada pela personagem é intercalada por falas da mulher que a escreve. Optou-se por manter esses marcadores, de modo que essa e as demais citações aqui apresentadas em itálico constituem as falas da chamada "mulher que me escreve".
} 
Considerando essa presença do outro na construção das forças repressivas que permeiam a vida de um ser humano, uma vez que este precisa de um outro que lhe dê as identidades para sua formação, Ronald David Laing (1989, p. 78) afirma: "todas as identidades exigem um outro - alguém em quem e através de cujo relacionamento a autoidentidade é efetivada". Dessa forma, a identidade conferida à personagem na obra Mulher no Espelho ilustra as ações a ela aplicadas contra a sua vontade. As determinações impostas por seu pai, as regras conservadas por seu marido, o sentimento de rejeição no âmbito familiar configurado a partir do nascimento de seu irmão e ainda a pseudo felicidade em que se alicerçava mascarando o verdadeiro comportamento de seus filhos, são todos fatores externos à personagem que lhe foram atribuídos pelo outro.

No rememorar dos acontecimentos, em diálogo com a mulher que a escreve, a personagem vai apresentando ao leitor os aspectos repressivos a que fora condicionada. Os primeiros traços repressivos versados na obra são constituídos com o nascimento do seu irmão. Este lhe retira as poucas regalias que a condição de filha única até tal momento lhe garantia. $\mathrm{O}$ colo, a ama e o espaço próximo aos pais que até o momento eram seus passaram a ser divididos com seu irmão. E a condição de irmã mais velha como exemplo ou companhia para o irmão mais novo modificou seu modo de vida, intensificando as regras a serem seguidas. Tal acontecimento pode ser evidenciado no trecho da obra: "Quando meu pai me proibia a praia ou o cinema e me mandava ficar em casa, fazendo companhia a meu irmão, eu não hesitava em obedecer" (CUNHA, 2001, p. 33). Além disso, a presença do filho de sexo masculino como o pai desejava se configurou como a necessidade de autopunição, segundo o olhar da personagem, por não ter dado ao pai a felicidade de ser um filho.

Outro aspecto marcador da relação repressiva, agora no tocante à sexualidade da personagem e já em sua fase adulta, refere-se à dicotomia da aceitabilidade diante da libertinagem sexual vivenciada pelo marido e a rejeição social pela mudança de comportamento da personagem no decorrer da trama. O marido gostava de se vangloriar com os amigos e conhecidos da família de sua potência sexual. Este era comumente encontrado em casos amorosos com quantas mulheres pretendesse não deixando escapar sequer a empregada da própria casa. Tal fato era de conhecimento das pessoas de convívio próximo, mas não chega a ser descrito como alvo de críticas por essas mesmas pessoas.

Já em relação à transformação ocorrida com a personagem, se no início era considerada modelo de esposa e de mãe por ser reservada e totalmente dedicada à família, ao trocar tal postura pela vivência das questões proibidas passou a ser criticada e malvista pelo meio familiar e social no qual estava inserida. Assim, se o comportamento do marido era aceito por todos, inclusive pela personagem esposa que o via levar a empregada para a própria cama sem esboçar qualquer reação, o comportamento da personagem (após sua mudança na narrativa), por envolver-se com o amigo do marido e com quantos outros homens desejasse, provocou uma reação social de discriminação e repulsa.

\section{CORPO APRISIONADO: VISÃO DA PROTAGONISTA ACERCA DE SUA CONDIÇÃO/ SEU ESTAR NO MUNDO}

Rememorando sua existência a personagem de Mulher no Espelho se vê lançada no questionamento de tudo o que viveu. Conforme Sheila Ferreira Leite (2004) por meio da memória essa personagem reconstrói seu passado representado pela menina-semsorriso, pela ama negra, pelo menino preto filho da cozinheira da casa do lado e pelos 
ratos do sótão onde ela era posta de castigo. A personagem lembra sua infância condicionada às ordens dadas pelo pai, ao silêncio submisso de sua mãe e aos cuidados e carinhos da ama negra que com o "áspero bom e morno" das mãos acarinhava-lhe o rosto.

A respeito das memórias da personagem, Maria Goretti Ribeiro (2004) afirma que elas são acionadas por meio da imaginação ativa, método utilizado por Carl Jung em estágios avançados da análise profunda que visa a estabelecer uma comunicação entre o ego e os conteúdos do inconsciente. E defende que, lançado no abismo do inconsciente, o eu (personagem da obra) busca o motivo de sua depressão no mundo minimizado da infância onde foram construídas suas primeiras perdas.

Os diferenciados níveis de comportamento e presença dentro da casa onde passou sua infância povoavam o imaginário dessa menina descrita como: menina boa, obediente, séria e fechada, com largo laço de fita no cabelo curto, levando no colo pequeno a boneca de louça quebrada, estudante na escola das freiras, que não podia brincar com os meninos pretos filhos das cozinheiras e dos pescadores.

No tocante à relação da personagem com o pai, esta se recorda das proibições do mesmo de que fosse à praia ou ao cinema e de vê-lo como alguém grande demais anulando todos ao seu redor, inclusive sua mãe, como cita no fragmento: "Insignificantes éramos todos nós, em volta dele, todo-poderoso, mandando e antimandando, e nós, aos seus pés, submissos, submetidos, subjugados, submergidos, subtraídos" (CUNHA, 2001, p. 33).

No que se refere à memória que possui de sua mãe, a personagem relata o comportamento desta com seu pai: "Toda cheirosa, à espera de que meu pai voltasse do trabalho. Ela o esperava. Perfumes, silêncios, sussurros. Seu sorriso pequeno" (CUNHA, 2001, p. 31). E acrescenta que nessa espera pelo marido a personagem a chamava, mas ela não a ouvia, e reafirma o silêncio da mãe que ao longo da trama é descrito como modelo para o seu silêncio ao passo que é também motivação para grande parte de sua revolta: "A sua voz pouca e leve. O seu silêncio denso. O altíssimo silêncio seu" (CUNHA, 2001, p. 34).

Ao longo da trama não há relatos de qualquer atitude da mãe para com a filha. Nos fragmentos em que a mãe é citada são mencionadas apenas as "atitudes" que tinha diante do marido. Tal aspecto demonstra que sua submissão às ordens determinadas pelo marido e sua anulação a tornava insignificante aos olhos da menina que, mesmo sem compreender o que passava, observava com atenção.

Nas suas lembranças da ama, porém, é relatado o pouco carinho com que contou em sua infância fazendo referência várias vezes ao áspero bom e morno das mãos da ama em seu rosto. Era com a ama também que a menina tentava esclarecer algumas de suas dúvidas fazendo-lhe perguntas. $\mathrm{E}$, do mesmo modo, era a ama que a arrumava, a acompanhava até a escola, cuidava de suas refeições, fazia-lhe companhia em casa. Um acontecimento que provocou grandes perdas, portanto, para a personagem foi $o$ nascimento de seu irmão. Este lhe tomou as atenções e cuidados da ama que até então, como a personagem conta, era só sua. Assim, o pouco carinho e atenção de que usufruía passou a ser dividido com o irmão. São narrados os desejos que a personagem possuía de machucá-lo ou até de eliminá-lo para ter de volta o colo que era só seu, ao passo que também é descrito o olhar da mulher que a escreve defendendo esse sentimento de perda que passava a compor a vida da personagem: "Você não podia ficar contente. Ele tomou o colo que até então era somente seu" (CUNHA, 2001, p. 20). E, segundo a personagem, 
eu brincava com meu irmão e quando me zangava, logo me arrependia. Mas uma vez, ele quebrou a minha boneca de louça [...] pare de chorar menina, eu quero a minha boneca, saia já daqui, eu não parava de chorar, a boneca sem rosto dizendo mamãe, cale esta boca menina, então eu quebrei o elefantezinho de meu irmão. De propósito, na frente dele. Fiquei de castigo presa no sótão. (CUNHA, 2001, p. 20)

$\mathrm{Na}$ sequência da narrativa, seu período de castigo no sótão configura o aparecimento dos ratos que, conforme relata a personagem, começaram a lhe roer os pés. Esses ratos surgem na obra como uma espécie de remorso, um meio de se auto castigar por alguma atitude que tenha tido e julgado incorreta. Assim, a respeito dos complexos formados pela personagem e o incômodo com os ratos que esta passou a sofrer a partir do nascimento de seu irmão, Carl Jung afirma:

está confirmado, pelo contrário, que os complexos possuem autonomia notável; que as dores sem fundamento orgânico, isto é, consideradas imaginárias, causam-nos sofrimento, tanto quanto as verdadeiras, e que a fobia de uma doença não revela a mínima tendência a desaparecer, ainda que o próprio doente, o médico e, para completar, o uso da linguagem assegurem que ela mais não é do que mera imaginação. (JUNG, 1991, p. 101)

Dessa forma, embora os ratos não existissem na realidade a personagem sofria com a perseguição destes como se existissem concretamente. E ainda como motivação para o aparecimento desses ratos uma vez que funciona como um distúrbio psíquico da personagem pode-se apontar a repressão sexual sofrida por ela. Isso ocorreu porque, conforme Marilena Chaú (1991, p. 19), com base nos estudos de Sigmund Freud, a libido não é a causa de doenças e distúrbios físicos e psíquicos, mas a causa deles se encontra na repressão da libido. O comportamento da personagem, portanto, nos momentos em que desobedecia às ordens repressivas do pai, ou simplesmente pensava em fazê-lo, entrava em choque tamanho com a formação por ela incorporada, ainda que forçadamente, que os ratos surgiam como castradores de sua pseudoliberdade, roendo-lhe os pés.

Segundo a mulher que escreve a história da personagem os ratos só existiam na imaginação desta, como uma espécie de remorso e autopunição diante de qualquer comportamento da personagem que contrariasse as ordens dominantes. Acerca da origem desses ratos, a personagem relata: "Os ratos começaram a me roer os pés. De onde vieram? De onde vinham? De uma das paredes do sótão pendia um espelho invadido de manchas cor de ferrugem. Me apavorei ante meu rosto no espelho. Queria gritar" (CUNHA, 2001, p. 21). Pela sequência da narrativa é possível notar que essas aparições de ratos para a personagem começaram após o nascimento de seu irmão e, consequentemente, após os seus desejos negativos em relação a ele, uma vez que o desejo do pai por ter um filho incomodava a personagem, como é relatado pela mulher que a escreve no trecho: "esta foi a sua primeira sensação de culpa. Por causa desta decepção primordial que você deu a seu pai, você procurou sempre, inútil tentativa, compensá-lo pela perda. A partir daí, você começou a traçar o seu caminho de obediência e submissão" (CUNHA, 2001, p. 67).

No que se refere à vida de adolescente a personagem comenta seu despreparo para abandonar a fase infantil: "Entre menina e moça, não conseguia dobrar a linha divisória. Do lado de cá, eu não cabia mais. Do outro lado não havia espaço" (CUNHA, 2001, p. 
34). Se definindo em tal fase como "boneca de papelão" ou "cara de caixa vazia" ela comenta o modo diferente das suas atitudes quando comparada às colegas de mesma idade. Muito inocente, reservada, dependente das permissões paternas, relata como sempre dizia não aos convites para cinema ou praia alegando não gostar desses passeios. Expõe também a sua ingenuidade diante de qualquer termo relativo à sexualidade, bem como seu puritanismo marcador da formação religiosa e conservadora a que fora submetida.

No referente à vida adulta, a personagem cita o seu casamento, a transmissão da ordem dominante do pai para o marido. Recorda as exigências do marido em relação a sua aparência para que não ficasse envelhecida e as proibições de que saísse sozinha condicionando-a apenas ao ambiente doméstico. Recorda também as várias traições do marido e a postura dos três filhos que a exploravam, desobedeciam, desrespeitavam, ridicularizavam. E, como resposta física a essas lembranças que se somam em seus aspectos repressivos, a personagem descreve o modo como se sente diante de tudo.

Em certos momentos, me sinto muito cansada. Desamanhecida, entorpeço ao dia grave e basto. Compactude. Desânimo pegajoso me escorrendo pelos membros, me emplastando os poros, estagnando-me o sangue nas veias. Inerciada e desnervada, abafo a minha substância. Os meus braços empedrados se recusam a qualquer gesto. Os pés dormentes se fecharam a passos e passagens. (CUNHA, 2001, p. 94)

E acrescenta: "não gosto de admitir que todo o meu sacrifício tenha sido estéril. Recuso-me ao desperdício do fazer-desfazer-refazendo tudo" (CUNHA, 2001, p. 95). Assim, é possível notar, após todo o processo de diálogo com a mulher que a escreve e as rememorações e reflexões que tal diálogo lhe impulsionou, já indícios do surgimento de um novo olhar da personagem em relação a tudo o que havia vivido. Se até tal fase esta se recusava a aceitar as críticas do espelho que afirmava os erros configurados em sua vivência, a partir de então passa a repensar os acontecimentos se preparando para uma experiência diferenciada.

\section{REFLEXOS DO ESPELHO E A TRANSFORMAÇÃO DA PERSONAGEM: UM OLHAR SOBRE O CORPO REAGENTE}

$\mathrm{Na}$ obra há um diálogo constante entre a personagem e a mulher que a escreve simulado pela presença do espelho no ir e vir de lembranças e reflexões. Assim, considerando a relação que vai se estabelecendo na obra entre a personagem e a mulher que a escreve, passa a ser descrita a nova percepção sobre o seu estar no mundo que a personagem vai assumindo. No processo de autoanálise em que está imersa ela repensa toda a sua vida, todos os seus relacionamentos, os sonhos ou até pequenos desejos abandonados, a omissão diante do rumo que sua vida tomava. Reflete acerca dos erros e acertos configurados nessa vivência e toda essa rememoração é atingida a partir dos impulsos do espelho que é ao mesmo tempo taxativo e interrogador. No entanto, os relatos em torno de sua vida são feitos por óticas diferenciadas. Se para o espelho um fato é refletido de uma forma, o mesmo fato é descrito por outro viés pela personagem.

Se a respeito da infância da protagonista a mulher que a escreve relatava as atitudes negativas da menina, atitudes severamente punidas por seu pai, e o porquê de cada ação, a protagonista dispensava toda e qualquer justificativa alegando que os castigos foram merecidos considerando o que ela havia feito, além de dispensar qualquer 
justificativa de cunho psicológico para tais ações. Assim, se havia feito algo que contrariasse as vontades e ordens do pai defendia o castigo aplicado, enquanto a mulher que a escreve a censurava por este sentimento de culpa alegando os vários motivos para cada atitude da personagem. A mulher que a escreve, deste modo, exibia como normal para uma criança, e posteriormente para uma adolescente e adulta, o comportamento da personagem quando esta se irritava, entristecia ou impacientava com os pais, com o irmão, ou com o marido e os filhos.

Considerando os traumas da personagem e essa postura de negação diante dos fatos, isso pode ocorrer devido aos seus mecanismos de defesa que se recusam a enxergar a realidade optando por outros olhares acerca do que acontece ao seu redor. Sobre os métodos de negação adotados pelo ego para evitar a "dor" de origem interna e externa, Ana Freud afirma o seguinte.

O método de negação, no qual se baseia a fantasia de inversão dos fatos reais nos seus opostos, é empregado em situações em que é impossível evitar uma impressão dolorosa externa [...]. Em vez de perceber a impressão dolorosa, e, subsequentemente, cancelá-la está ao alcance do ego recusar o encontro com a situação perigosa externa. Pode fugir-lhe e, assim, no mais verdadeiro sentido da palavra, 'evitar' as ocasiões de 'dor'. (FREUD, 1996, p. 80)

Tal postura de defesa evitando o sentimento de dor é um comportamento recorrente da personagem de Mulher no Espelho ao negar as afirmações feitas pela mulher que a escreve e relatar uma versão diferenciada. Isso acontece uma vez que o ego, conforme Laplanche e Pontalis, representa o polo defensivo da personalidade.

Em suas primeiras lembranças a personagem se vê questionada sobre a origem de seu perfil autopunitivo ainda na infância. Segundo a mulher que a escreve a personagem tem como primeiro motivador para a autorrejeição o seu sexo, uma vez que nascendo mulher contrariou o desejo de ter um filho nutrido por seu pai. Somado ao fator citado, o nascimento do irmão concretizando a vontade do pai e a simultânea perda do colo de que desfrutava sendo filha única, dos cuidados da ama até então voltados para si e a intensificação das ordens a serem seguidas (para que fosse um bom exemplo para este irmão) tudo contribuiu para reforçar a anulação de desejos da personagem, comportamento este que ela já começava a esboçar constituindo o corpo aprisionado, dominado. Nesse sentido, o espelho afirma tal comportamento como sendo o princípio da vida manipulada que a personagem permite seguir. Se no início da narrativa a personagem afirma apenas questões positivas no que se refere à sua criação, no decorrer da trama passa a considerar as afirmações referentes a uma infância conturbada, afirmações levantadas pela mulher que a escreve. Isso é demonstrado no fragmento a seguir, que relata o olhar da personagem já adulta diante da casa onde passou sua infância.

Olho para a minha antiga casa, hoje quase em ruínas. Afirmar que não me emociono é falso. Sinto um nó na garganta, gastura, respiro fundo, procuro vencer a vontade de vomitar. Parece-me estranho ouvir as pessoas aludirem à saudade que sentem do passado. Por que saudades? Por acaso os dias já vividos serão menos tristes do que os do presente? (CUNHA, 2001, p. 86)

E rememorando cenas da infância, como sua participação nas procissões, vestida de anjo, o que considerava o seu momento de realização, a personagem relata a sua última 
participação em tal evento. Descreve como, devido à ansiedade que não a permitia comer corretamente, se sentiu mal durante o trajeto e começou a vomitar em meio à procissão, além dos resquícios desse acontecimento. E, conforme o olhar da mulher que a escreve, acerca da infância da personagem e o sentimento por esta descrito,

todas as vezes em que você passa pela casa da sua infância, você não pode sentir saudades daquele tempo. Você só pode ter muita vontade de vomitar e sabe por quê? A revolta reprimida. O nojo de uma estrutura familiar completamente insensível aos seus pequenos anseios, os minúsculos sonhos. (CUNHA, 2001, p. 90)

Do mesmo modo ocorre no tocante à adolescência e sua vida adulta, se a personagem começa narrando o desenrolar de uma vivência feliz e satisfatória tal postura não é perpetuada pela mulher que a escreve. São descritas as ordens do pai e a forma como a personagem se sentia diante delas na adolescência, bem como a desvalorização em sua família na fase adulta.

E sobre o comportamento dos filhos e do marido já na voz da personagem, embora cite como ponto de vista da mulher que a escreve: "ela, a mulher que me escreve, insiste em chamar a atenção para as vezes em que meu marido e meus filhos se levantaram da mesa, sem comer, resmungando resmungões ou zangados, jogando a comida fora do prato ou no chão ou em cima de mim" (CUNHA, 2001, p. 41).

Já em relação ao comportamento do marido da personagem, desfazendo a imagem ilusória que a personagem faz dele, a partir da voz da mulher que a escreve, são relatadas cenas de infidelidade e violência.

Como daquela vez em que ele obrigou a empregada a se sentar à mesa para comer e depois simplesmente foi para a cama com ela. E você? Onde você se escondeu para fingir que não estava vendo a sacanagem? Quantas vezes ele chegou à casa embriagado e quebrou a louça e os copos? Quantas vezes ele já bateu em você? Basta de fingir e fantasiar felicidade que não é. (CUNHA, 2001, p. 41-42)

O processo de reflexão impulsionado pelo frente a frente com o espelho é o que vai esclarecendo para a personagem a derrota de valores em que se pautou a sua existência. Assim, a negação de fatos que esta fazia como um meio de atenuar sua decepção diante da realidade que lhe era desnudada alcança uma proporção que já não pode ser mantida. Essa negação inicial ocorre porque como defende Carl Jung (1991) os traumas compõem as verdadeiras unidades da psique inconsciente, logo, a personagem não poderia estar, pelo menos a princípio, consciente dos aspectos apontados pelo espelho. E conforme Sigmund Freud (1975) o conceito de inconsciente é formulado a partir da teoria da repressão, sendo o reprimido a base do inconsciente. Portanto, o processo de tornar conscientes as ações repressivas exercidas sobre a personagem tornouse possível mediante as ações de rememoração e reflexão impulsionadas pela mulher que a escreve.

A personagem que inicialmente resiste às afirmações apontadas pelo espelho recusando como verdades aquilo que já estava concretizado se vê lançada em comprovações das quais já não pode fugir e afirma sua necessidade de enxergar os fatos: "Preciso ver claro, mesmo sabendo que não verei claro. As infinitas faces da verdade. [...] o que haverá atrás dos espelhos? Os espelhos quebrados" (CUNHA, 2001, p. 134). A 
mulher que a escreve, por sua vez, relata as motivações para o ódio reprimido que compõe a vivência da personagem e o comportamento autopunitivo da mesma: "você pensa que não se revolta porque se cala, não explode, mas rumina, mastigando os pedaços que você engoliu sem digerir e que ainda hoje ficaram atravessados no seu vômito e no seu nojo" (CUNHA, 2001, p. 90).

O comportamento da mulher que a escreve então que antes era criticado e rejeitado pela personagem passa a ser norteador para as ações da protagonista. Assim, a personagem ensaia a transformação de comportamento tomando como base tudo o que lhe fora proibido. O impactante da obra, nesse caso, é a mudança de olhar a respeito das censuras do espelho. A personagem a partir do seu choque de percepções, entre o que havia se habituado a enxergar no seu processo de autoengano e o que realmente tinha sofrido e continuava a sofrer, passa a viver conforme as opiniões anteriormente expressas pelo espelho. No entanto, diferente do que se poderia esperar, a partir de tal acontecimento a mulher que a escreve ao invés de apoiá-la e auxiliá-la na vivência dessa nova fase continua a censurá-la, mas agora no sentido inverso.

A mudança da personagem de um polo a outro, portanto, provocou também a transformação na ordem da crítica que recebia do espelho. Se inicialmente era contestado o seu comportamento submisso frente aos desmandos do marido, passou a ser alvo de questionamentos e recriminações a sua postura considerada libertina por esse mesmo espelho. Se antes era questionada pelo seu comportamento de permissividade em relação aos filhos e a anulação de sua vida em razão destes, passou a ser censurada ao deixá-los de lado. E, do mesmo modo, se era criticada pelo seu excesso de conservadorismo, pela negação de seus desejos sexuais, a crítica foi deslocada para o exercício das práticas sexuais sem qualquer restrição que passou a compor o cotidiano da personagem. Isso é evidenciado na fala da mulher que a escreve.

Você não pode continuar a levar essa vida irregular, ora com um, ora com outro. Você parece ter esquecido aquele infeliz, que quase matou a esposa e o filho por sua causa. Você precisa regularizar a sua vida. Precisa pensar nos seus filhos. Eles estão precisando de você mais do que nunca. (CUNHA, 2001, p. 139)

Já conforme o olhar da personagem sobre essa mudança de opinião da mulher que a escreve (indo ao sentido oposto ao que pregava anteriormente), bem como acerca da linguagem utilizada pela autora, que, segundo a personagem, tenta conter o ímpeto de suas explosões, e ainda como resposta à constante preocupação da sociedade com as aparências, a personagem relata:

a mulher que me escreve, tomada de remorsos, começa um processo de arrependimento galopante, que lhe dá um ar de falso puritanismo, em desacordo com as convicções que alardeou durante toda a sua vida, até há pouco tempo. Quanto à autora, embora se diga liberal, está preocupada em atenuar o ímpeto das minhas explosões, em meias palavras, breves sugestões, como se fosse ofensa aos bons costumes a descrição minuciosa das minhas primeiras experiências amorosas com o amigo do meu marido. (CUNHA, 2001, p. 121)

Tal fato revela o conflito psíquico em que estava imersa a personagem, uma vez que há em toda a obra, inclusive após essa transformação da personagem, uma contradição entre o ponto de vista da personagem e o da mulher que a escreve. Há, por 
conseguinte, um conflito entre o impulso do prazer que a personagem almejava e a pressão da realidade repressora simulada pela voz da mulher que a escreve. A esse respeito, Laplanche afirma que se fala em conflito quando no indivíduo se opõem exigências internas contrárias. Assim, o conflito pode ser manifestado entre um desejo e uma exigência moral ou entre dois sentimentos contraditórios.

Superando esses conflitos, porém, e em resposta à censura feita pela mulher que a escreve, nessa fase de sua vida, a personagem declara os contrapontos entre o modo como havia vivido até então e a ruptura com esse modo de vida. A personagem passa a contrariar as regras em que fora criada, vivendo sua sexualidade conforme seus desejos.

Eu, a mãe de família exemplar, a filha obediente e abnegada, a esposa casta e cheia de virtudes, eu, a tímida e a pura, a inocente e a ingênua, eu, eu, proclamo a legitimidade do prazer praticado por livre vontade e com a pessoa escolhida independente de vínculos matrimoniais. (CUNHA, 2001, p. 122)

Ao fim do romance, no entanto, após a vivência dos itens proibidos, proibições que condicionaram praticamente toda a vida da personagem a uma existência reprimida, esta, aparentemente vencida pelas pressões exteriores, mostra-se sem forças e já sem vontades.

Na verdade, não consigo mais sentir como eu sentia. Às vezes, noto que sinto absolutamente nada. Apenas sensações. Nem alegria nem tristeza. Nem mágoa nem angústia. Nem nojo nem pena. Como se já tivesse sentido tudo que tinha para sentir. Acabou. Não. Ainda sinto irritação. Sinto cansaço sinto tédio. Mais nada. (CUNHA, 2001, p. 134)

Isso ocorreu como resultado das pressões exteriores à personagem, pressões da realidade repressora na qual fora criada e que continuou a reprimi-la a partir da voz do outro, através da censura social, que pôs em choque constante o impulso do prazer almejado pela personagem e essa pressão da realidade.

A sensação de vazio relatada pela personagem ao final da trama é descrita por Ronald Laing (1989) como o resultado quando a pessoa não se coloca naquilo que está fazendo ou quando se coloca em atos que lhe parecem ter significado, mas não recebe o reconhecimento alheio. Considerando que a personagem nunca fora reconhecida no período em que agia conforme as regras sociais pré-estabelecidas, mas que também não encontrou apoio na sua vivência contrária aos padrões sociais (vivência posterior à sua transformação), ela tem sua história finalizada na sensação de vazio de quem já tentara as aparentes possibilidades de uma vivência satisfatória, mas todas lhe foram frustradas.

Minha estória vai terminar. Tudo que eu poderia querer, já quis. Acabou. Percorremos nosso caminho até o último passo. Agora estamos paradas, uma olhando para a outra, os pés roídos de ratos. Os espelhos multiplicam as imagens até ao infinito. Mas nosso remorso nos une. $\mathrm{O}$ cheiro de rato sufoca o cheiro que vem da mangueira milenar. (CUNHA, 2001, p. 174)

Sua história é encerrada, portanto, sem qualquer previsão de melhorias e marcada pelo mesmo peso do remorso com que fora iniciada, porém, tal remorso passou a compor não só a personagem, mas o seu reflexo no espelho ilustrado pela mulher que a escreve. 


\section{CONSIDERAÇÕES FINAIS}

É possível considerar que na obra Mulher no Espelho foram identificados meios de aprisionamento do corpo através do comportamento dos familiares da personagem: pai, mãe, irmão, marido e filhos, bem como pelo espelho categórico que reflete a visão de censura da "mulher que me escreve". Além disso, também foram identificados como instrumentos de aprisionamento o corpo da personagem e suas reações, ou a ausência de reações, face aos traumas que se formaram ainda na infância e se alastraram pela adolescência e vida adulta.

Portanto, além das forças repressivas exteriores à personagem, esta também se autorreprimia, se autocensurava, segundo os relatos da mulher que a escreve, fazendo do seu corpo um espaço de aprisionamento. Por essa razão, é perceptível no romance fragmentos em que o corpo da personagem é descrito como cansado, sem forças, já que respondeu dessa forma a várias pressões externas e às pressões do seu inconsciente. À medida que suas memórias dolorosas vão sendo desnudadas, a personagem já não tendo uma rota de fuga que a inconsciência dos fatos lhe conferia abandona a fase de negação (que consistiu num método de autoproteção) e, estando consciente dos rumos seguidos por sua vida e dos aprisionamentos aos quais sempre estivera condicionada, tenta romper com os padrões impostos e vivenciar as questões que lhe foram sempre proibidas.

Na referida tentativa, no entanto, a personagem se vê lançada em meio às críticas ainda mais taxativas e repressivas, de modo que a vivência dessa etapa que deveria constituir o corpo libertado e auto libertado termina constituindo outro sentido repressivo. Entra em choque, por conseguinte, os impulsos da personagem desejando um modo de vida diferenciado e as pressões da realidade repressora que respondia no sentido de fazer com que esta retornasse ao seu comportamento inicial. A obra retrata, assim, as tentativas do corpo aprisionado de romper com as ordens dominantes visando uma reconstrução de si. Corpo que em seu salto de reação se vê tomado pela força das pressões sociais, sendo obrigado a recuar à condição inerte em que sempre esteve e as pressões esperam perpetuar.

\section{REFERÊNCIAS}

CHAUÍ, M. Repressão sexual essa nossa (des)conhecida. 12a . ed. São Paulo: Brasiliense, 1991. CUNHA, Helena Parente. Mulher no espelho. 8a. ed. Rio de Janeiro: Tempo Brasileiro, 2001.

CUNHA, Helena Parente. Além de estar: antologia poética. Rio de Janeiro: Imago, 2000. FREUD, Anna. O ego e os mecanismos de defesa. Trad. Bras. 10ª ed. Rio de Janeiro: Civilização Brasileira, 1996.

FREUD, S. O ego e o id. Trad. Bras. Rio de Janeiro: Imago, 1975.

JUNG, C.G. A dinâmica do inconsciente. Trad. Bras. 2a ${ }^{\mathrm{a}}$. ed. Petrópolis: Vozes, 1991.

LAING, R.D. O eu e os outros: o relacionamento interpessoal. Trad. Bras. $7^{\text {a }}$. ed. Petrópolis: Vozes, 1989.

LAPLANCHE, J.; PONTALIS, J.-B. Vocabulário da Psicanálise. Trad. Bras. 9ª ed. São Paulo: Martins Fontes, 1986.

LEITE, Sheila Ferreira. Em busca de uma identidade de Mulher no Espelho. Em: SILVA, Antônio de Pádua Dias da; RIBEIRO, Maria Goretti. Mulheres de Helena: trilhamento do feminino na obra de Parente Cunha. João Pessoa: Editora da UFPB, 2004. 
Artigo recebido em: fevereiro de 2018.

Aprovado e revisado em: agosto de 2018.

Publicado em: dezembro de 2018.

\section{Para citar este texto:}

LIANDA, Silvana Nascimento. Entre o reprimido e o liberto: uma leitura do corpo em Mulher no Espelho, de Helena Parente Cunha. Entremeios [Revista de Estudos do Discurso, ISSN 21793514, on-line, www.entremeios.inf.br], Seção Temática [Discurso, arte e literatura - Parte II], Programa de Pós-Graduação em Ciências da Linguagem (PPGCL), Universidade do Vale do Sapucaí (UNIVÁS), Pouso Alegre (MG), vol. 17, p. 247-262, jul. - dez. 2018.

DOI: http://dx.doi.org/10.20337/ISSN2179-3514revistaENTREMEIOSvol17pagina247a262 